\title{
UNIVERSITY OF BONN NATURAL RADIOCARBON MEASUREMENTS VI
}

\section{H. W. SCHARPENSEEL and F. PIETIG}

Institut für Bodenkunde, Universität Bonn

Bonn, Bundesrepublik Deutschland

Continuation of radiocarbon measurements, mainly on ground water, soil, and subhydric sediment samples. Sample preparation was described earlier (Scharpenseel and Pietig, 1969).

\section{ACKNOWLEDGMENTS}

Much of the technical sample preparation was done by $\mathrm{E}$. Kruse, H. Tapp, Chr. Haupenthal, H. Schillmann, and K. Kirschey. The Gesellschaft für Mathematik und Datenverarbeitung helped us with their computer facilities in the calculations. The work was financed mainly by the Federal Department of Education and Science. Travel funds for sampling outside Germany were provided by the German Foundation of Research (Deutsche Forschungsgemeinschaft).

\section{SAMPLE DESCRIPTIONS}

\section{A Cologne 07 sand aquifer}

After 3 yr repetitions of radiocarbon measurcments from 1967 to 1969 (R., 1968, v. 10, p. 8-28; 1969, v. 11, p. 3-14; 1970, v. 12, p. 19-39) a 4 th sampling and measurement was done in 1971. Since the 3 sets of dates (1967-1969) did not allow flow speed calculation from movement of bomb-carbon peak, due to geologic ruptures, mixing and unsteady flow-pattern (Tamers and Scharpenseel, 1970), further tests at intervals of several yr are expected to yield new data.

\begin{tabular}{|c|c|}
\hline Samples Kölner Bucht & $\begin{array}{l}\text { Measured } \\
\mathrm{C}^{14} \text { age }\end{array}$ \\
\hline $\begin{array}{l}\text { BONN-1227. Synthern } 93730 / 4 \\
\left(50^{\circ} 58^{\prime} \mathrm{N} \text { Lat, } 6^{\circ} 47^{\prime} \mathrm{E} \text { Long }\right)\end{array}$ & $\begin{array}{l}1940 \pm 100 \\
\text { A.D. } 10 \\
2050 \pm 60\end{array}$ \\
\hline $\begin{array}{l}\text { BONN-1228. Glessen } 93715 / \mathrm{I} \\
\left(50^{\circ} 58^{\prime} \mathrm{N} \text { Lat, } 6^{\circ} 45^{\prime} \mathrm{E} \text { Long }\right)\end{array}$ & $\begin{array}{c}100 \text { в.C. } \\
10,270 \pm 160\end{array}$ \\
\hline $\begin{array}{l}\text { BONN-1229. Dansweiler } 93732 / 4 \\
\left(50^{\circ} 57^{\prime} \mathrm{N} \text { Lat, } 6^{\circ} 46^{\prime} \mathrm{E} \text { Long }\right)\end{array}$ & $\begin{array}{l}8320 \text { в.C. } \\
1470 \pm 70\end{array}$ \\
\hline $\begin{array}{r}\text { BONN-1230. Widdersdorf } 83002 / 2 \\
\left(50^{\circ} 58^{\prime} \mathrm{N} \text { Lat, } 6^{\circ} 50^{\prime} \mathrm{E} \text { Long }\right)\end{array}$ & $\begin{array}{l}\text { A.D. } 480 \\
7840 \pm 220\end{array}$ \\
\hline $\begin{array}{l}\text { BONN-1231. Ingendorf } 83114 / 3 \\
\left(51^{\circ} 1^{\prime} \mathrm{N} \text { Lat, } 6^{\circ} 44^{\prime} \mathrm{E} \text { Long }\right)\end{array}$ & 5890 в.с. \\
\hline
\end{tabular}




\begin{tabular}{cc}
\hline Samples Kölner Bucht & $\begin{array}{c}\text { Measured } \\
\mathrm{C}^{14} \text { age }\end{array}$ \\
\hline BONN-1232. Königsdorf 83131/3 & $22,610 \pm 500$ \\
$\left(50^{\circ} 56^{\prime}\right.$ N Lat, $6^{\circ} 46^{\prime}$ E Long) & 20,660 B.C. \\
BONN-1233. Bottenbroich $85075 / 4$ & $6220 \pm 110$ \\
$\left(50^{\circ} 55^{\prime}\right.$ N Lat, $6^{\circ} 44^{\prime}$ E Long) & 4270 B.C. \\
BONN-1234. Buschbcll 85089/2 & $8860 \pm 120$ \\
$\left(50^{\circ} 56^{\prime}\right.$ N Lat, $6^{\circ} 48^{\prime}$ E Long $)$ & 6910 B.C. \\
BONN-1235. Herbertzkaul 85197/3 & $10,600 \pm 140$ \\
$\left(50^{\circ} 54^{\prime}\right.$ N Lat, $6^{\circ} 48^{\prime}$ E Long) & 8650 B.C. \\
\hline
\end{tabular}

Comment: samples from piezometric tubes Ingendorf and Königsclorf shifted towards considerably older age, Widdersdorf dropped correspondingly. Two further sets of samples in 2 or $3 \mathrm{yr}$ intervals expected to eluciclate rather complicated flow and recharge pattern of highly exploited aquifer.

\section{SOIL SAMPLES}

Methods of pretreating soil samples are compared and reviewed clsewhere (Scharpenseel and Pietig, 1969; Scharpenseel, 1972).

\section{A. Spain}

Dates belong to continued natural radiocarbon measurements in Vertisols (sce R., 1973, v. 15, p. 23-25, II A to D). Profiles are from Andalusia, S Spain with help of local pedologists.

Vertisol, rich in swelling and cracking clay, La Rimconada (Sevilla), Cilsas vacas, $20 \mathrm{~m}$ above $\mathrm{NN}, 18.5^{\circ} \mathrm{C}$ ann. $\mathrm{t}, 559 \mathrm{~mm}$ ann. rainfall, plain ( $37^{\circ} 23^{\prime} \mathrm{N}$ Lat, $2^{\circ} 12^{\prime} \mathrm{W}$ Long). Samples from same location.

BONN-1388. Vertisol La Rimconada, $1.7 \% \mathrm{C}$, Ap 20 to $30 \mathrm{~cm}$

BONN-1389. $0.8 \%, \mathrm{C}, \mathrm{ABv} 40$ to $50 \mathrm{~cm}$

BONN-1390. $0.6 \%$ C, Bv 75 to $95 \mathrm{~cm}$

BONN-1391. $0.4 \%$ C, BvCal 125 to $145 \mathrm{~cm}$

BONN-1392. $0.3 \%$ C, BvCa2 160 to $180 \mathrm{~cm}$

$$
\begin{gathered}
590 \pm 70 \\
\text { A.D. } 1960 \\
1570 \pm 80 \\
\text { A.1. } 380 \\
2840 \pm 160 \\
890 \text { в.C. } \\
3160 \pm 160 \\
1210 \text { B.C. } \\
6470 \pm 190 \\
4520 \text { в.C. }
\end{gathered}
$$


Vertisol, Carmona, $\mathrm{km} 10.5$ Carmona-Arahal St., $75 \mathrm{~m}$ above NN, $19^{\circ} \mathrm{C}$ ann. t., $540 \mathrm{~mm}$ ann. rainfall, marl, $\left(37^{\circ} 25^{\prime} \mathrm{N}\right.$ Lat $1^{\circ} 55^{\prime} \mathrm{W}$ Long). Samples from same location.

BONN-1393. Vertisol, Carmona, $0.7 \% \mathrm{C}, \mathrm{Bvl} 10$ to $30 \mathrm{~cm}$ $2410 \pm 70$ 460 B.C.

BONN-1394. $1.0 \%$ C, Bv2 30 to $50 \mathrm{~cm}$ $3150 \pm 80$ 1200 B.C.

BONN-1395. 2.8\% G, Bv3 80 to $100 \mathrm{~cm}$

$4480 \pm 90$ 2530 B.C.

BONN-1396. 1.0\% Ci, Call 130 to $140 \mathrm{~cm}$ $5510 \pm 100$ 3560 B.C.

BONN-1397. $0.5 \%$ C, Cca2 $>150 \mathrm{~cm}$ $6650 \pm 120$ 4700 B.c.

Vertisol, Los Palacios, Farm Torbiscal, $18^{\circ} \mathrm{C}$ ann. t., $600 \mathrm{~mm}$ ann. rainfall, alluvial soil, $\left(37^{\circ} 4^{\prime} \mathrm{N}\right.$ Lat, $2^{\circ} \mathrm{I} 0^{\prime} \mathrm{W}$ Long). Samples from same location.

BONN-1398. Vertisol, Los Palacios, $3.4 \%$ C, Apl 5 to $15 \mathrm{~cm}$

$$
\begin{gathered}
1580 \pm 70 \\
\text { A.D. } 370 \\
2080 \pm 80 \\
130 \text { B.C. } \\
2580 \pm 70 \\
630 \text { B.C. }
\end{gathered}
$$

BONN-1399. 2.6\% C, Aplisv1 20 to $35 \mathrm{~cm}$

BONN-1400. 2.3\% C, Bv21 35 to $50 \mathrm{~cm}$

BONN-1401. $2.3 \% \mathrm{C}, \mathrm{Bv} 2155$ to $70 \mathrm{~cm}$ $6350 \pm 140$ 4400 B.C.

BONN-1402. $3.2 \%$ G, Bv21 80 to $100 \mathrm{~cm}$ $4940 \pm 90$ 2990 B.C.

BONN-1403. $0.9 \%$ C, Bv22 110 to $130 \mathrm{~cm}$

$8850 \pm 130$ 6900 B.C.

BONN-1405. $0.3 \%$ C, Ccal 170 to $200 \mathrm{~cm}$ $7660 \pm 130$ 5710 B.C.

BONN-1406. 0.4\% C, Cca2 $>200 \mathrm{~cm}$ $7510 \pm 140$ 5560 B.C.

Vertisol, El Arahal, Farm l'Estrella, 40km E Sevilla, 60 to $80 \mathrm{~m}$ above $\mathrm{NN}, 19.5^{\circ} \mathrm{C}$ ann. $\mathrm{t}, 518 \mathrm{~mm}$ ann. rainfall, plain, alluvial sand cover on top of Vertisol, $\left(37^{\circ} 15^{\prime} \mathrm{N}\right.$ Lat, $1^{\circ} 53^{\prime} \mathrm{W}$ Long). Samples from same location.

BONN-1407. Vertisol, El Arahal, $1.4 \% \mathrm{~S}, \mathrm{Apl} 5$ to $15 \mathrm{~cm}$

$$
\begin{gathered}
108.4 \pm 0.6 \% \\
\text { Modern }
\end{gathered}
$$


BONN-1408. $1.0 \% \mathrm{C}, \mathrm{A}_{\mathrm{P}} 217$ to $30 \mathrm{~cm}$ A.D. 1260

$690 \pm 70$

BONN-1409. $0.3 \%$ C, Bvl 32 to $42 \mathrm{~cm}$

$2320 \pm 90$

370 в.c.

BONN-1410. $1.4 \% \mathrm{C}$, Bv2 47 to $59 \mathrm{~cm}$

$3640 \pm 50$

1690 B.C.

BONN-1411. 1.4\% C, Bv2 61 to $70 \mathrm{~cm}$

$3480 \pm 100$

1530 B.C.

BONN-1413. $0.2 \%$ C, CalBv9 90 to $104 \mathrm{~cm}$

$3520 \pm 230$

1570 в.c.

Vertisol, Carmona, Far, la motilla chica, $160 \mathrm{~m}$ above $\mathrm{NN}, 19^{\circ} \mathrm{C} \phi$ ann. t, $540 \mathrm{~mm}$ o ann. rainfall, plain, pebbles of old Quaternary terrace sediment intermixed, (37 $28^{\prime} \mathrm{N}$ Lat, $1^{\circ} 49^{\prime} \mathrm{W}$ Long). Samples from same location.

BONN-1417. Vertisol, Cammona, Far, $2.4 \% C, A p 5$ to $12 \mathrm{~cm}$

$$
\begin{gathered}
103.3 \pm 0.5 \% \\
\text { Modern } \\
730 \pm 70 \\
\text { A.D. } 1220
\end{gathered}
$$

BONN-1418. $1.5 \%$ C, Ap 16 to $25 \mathrm{~cm}$

BONN-1419. $1.2 \%$ C, AB 36 to $48 \mathrm{~cm}$

$1710 \pm 80$

A.D. 240

$2710 \pm 70$ 790 в.с.

BONN-1420. $1.0 \% \mathrm{C}, \mathrm{B} 2 \mathrm{2} 61$ to $82 \mathrm{~cm}$

$2750 \pm 140$

800 B.C.

$3140 \pm 290$

1490 в.с.

BONN-1423. $0.3 \%$ Ci, II Cia 108 to $128 \mathrm{~cm}$

Samples coll. and subm. 1970 by W. Kerpen and H. Gewehr, Inst. Bodenkunde, Bonn. Comment: last 2 profiles, El Arahal and Carmona Far show to the full depth about the same apparent mean residence time (Scharpenscel, 1972), indicating transport of surface material through cracks and self-mulching. La Rimconacla and Cammona profiles have an age break at ca. $100 \mathrm{~cm}$, Ios Palacios at ca. $70 \mathrm{~cm}$ with steep increase of C-residence times in downward direction, below the crack zone.

\section{B. Portugal}

The Portugal series contributes 7 Barros profiles to the natural radiocarbon measurements in Vertisols. Profiles are sclected in central and $S$ Portugal with help of local pedologists.

Vertisol, black Barros, Béja, free of $\mathrm{CaCO}_{3}, 250 \mathrm{~m}$ above NN $\left(38^{\circ}\right.$ $0^{\prime} \mathrm{N}$ Lat, $1^{\circ} 16^{\prime} \mathrm{W}$ Long). Samples from same location. 
BONN-1425. Vertisol, Beja, $0.6 \%$ C, Ap 2 to $7 \mathrm{~cm}$

$$
\begin{gathered}
101.0 \pm 0.4 \% \\
\text { Modern } \\
330 \pm 100
\end{gathered}
$$

BONN-1426. $0.9 \%$ G, B11 10 to $18 \mathrm{~cm}$

A.D. 1620

BONN-1427. $1.9 \%$ C, B12 24 to $37 \mathrm{~cm}$

BONN-1428. $3.0 \%$ C, B13 43 to $52 \mathrm{~cm}$

BONN-1429. $3.1 \%$ C, B14 58 to $72 \mathrm{~cm}$

BONN-1432. $0.2 \%$ C, Cca 120 to $130 \mathrm{~cm}$
$1550 \pm 70$

A.D. 400

$1220 \pm 70$ A.D. 730

$2000 \pm 120$

50 в.с.

$3070 \pm 140$

1120 B.C.

Brown Mediterranean soil till Vertisol, Safara-Camauros Farm, $180 \mathrm{~m}$ above NN, hilly, (38 $5^{\prime} \mathrm{N}$ Lat, $1^{\circ} 52^{\prime} \mathrm{W}$ Long). Samples from same location.

BONN-1433. Vertisol, Safara-Camauros, $0.4 \% \mathrm{C}, \mathrm{Ap} 20$ to $32 \mathrm{~cm}$

$300 \pm 80$ A.D. 1650

BONN-1434. $0.3 \%$ C, BC 45 to $55 \mathrm{~cm}$

$2430 \pm 70$ 480 B.C.

BONN-1436. $0.3 \%$ C, BC 55 to $69 \mathrm{~cm}$

$1870 \pm 90$ A.D. 80

BONN-1437. $0.3 \%$ C, Ci 70 to $90 \mathrm{~cm}$

$2140 \pm 220$

190 B.c.

Black Vertisol, not totally frce of $\mathrm{CaCO}_{3}$, Safara (field), $197 \mathrm{~m}$ above $\mathrm{NN}$, hilly, (38 $5^{\circ} \mathrm{N}$ Lat, $1^{\circ} 51^{\prime} \mathrm{W}$ Long). Samples from same location.

BONN-1438. Vertisol, Safara, field, $0.4 \% \mathrm{C}, 1 \mathrm{~B} 23$ to $32 \mathrm{~cm}$

BONN-1439. $0.5 \%$ C, IB 33 to $44 \mathrm{~cm}$

BONN-1440. $0.8 \%$ C, IB 44 to $54 \mathrm{~cm}$

BONN-1441. $0.3 \%$ C,IIBca 56 to $67 \mathrm{~cm}$

BONN-1442. $0.3 \%$ G, IICca 72 to $95 \mathrm{~cm}$
$970 \pm 70$

A.D. 980

$1490 \pm 80$

A.D. 460

$2190 \pm 80$

240 B.C.

$2230 \pm 190$

280 B.c.

$1860 \pm 100$

A.D. 90

Red Vertisol, secondarily recalcified, Salvada-Beja, $195 \mathrm{~m}$ above NN, slightly slopy, $\left(37^{\circ} 56^{\prime} \mathrm{N}\right.$ Lat, $1^{\circ} 20^{\prime} \mathrm{W}$ Long). Samples from same location. 
BONN-1443. Vertisol, Salvada-Beja, $1.0 \% \mathrm{C}$, Ap 15 to $32 \mathrm{~cm}$

$103.3 \pm 0.4 \%$

Modern

BONN-1444. $1.2 \%$ C, B 41 to $51 \mathrm{~cm}$ $104.4 \pm 0.5 \%$ Modern

BONN-1445. $0.5 \% \mathrm{C}, \mathrm{B} 52$ to $65 \mathrm{~cm}$ A.D. 1350

$$
600 \pm 70
$$

BONN-1446. $0.5 \%$ C, BC 71 to $85 \mathrm{~cm}$

$$
1380 \pm 70
$$

A.D. 570

Roman Cereal silo in Vertisol profile, Beja-Serpa, $150 \mathrm{~m}$ above NN, street cut, hilly, ( $37^{\circ} 54^{\prime} \mathrm{N}$ Lat, $1^{\circ} 27^{\prime} \mathrm{W}$ Long).

BONN-1447. Cereal silo Vertisol, Beja-Serpa, $0.3 \%$ C, $\quad 5150 \pm 100$ 0 to $20 \mathrm{~cm}$ from deepest point of cut 3200 B.C.

BONN-145I. $0.8 \%$ C, 35 to $50 \mathrm{~cm}$

$$
1320 \pm 70
$$

A.D. 630

Dark red-brown Vertisol, not completely free of $\mathrm{CaCO}_{3}$, Montes velhos Aljustrel, $104 \mathrm{~m}$ above $\mathrm{NN}$, slightly slopy $\left(37^{\circ} 55^{\prime} \mathrm{N}\right.$ Lat, $0^{\circ} 57^{\prime}$ W Long). Samples from same location.

BONN-1452. Dark red-brown Vertisol, Montes-velhos Aljustrel, $0.8 \% \mathrm{C}$, Ap 28 to $43 \mathrm{~cm}$ A.D. 990

$$
960 \pm 100
$$

BONN-1453. $0.6 \%$ C, B 47 to $62 \mathrm{~cm}$ A.D. 330

BONN-1454. $0.5 \% \mathrm{C}, \mathrm{B} 67$ to $83 \mathrm{~cm}$

$$
\begin{aligned}
& 2240 \pm 80 \\
& 290 \text { B.C. }
\end{aligned}
$$

BONN-1455. $\quad 0.5 \%$ C, B 87 to $103 \mathrm{~cm}$

$$
1970 \pm 150
$$

20 B.C.

BONN-1457. $0.3 \%$ C, Cca 140 to $150 \mathrm{~cm}$

$2000 \pm 110$

50 B.C.

Red-brown Vertisol almost purely montmorollinitic, Terra Grande de Lisboa, Tapaiao da Ajuda, univ. campus, near Lisboa, $73 \mathrm{~m}$ above $\mathrm{NN}, 16.9^{\circ} \mathrm{C} \phi$ ann. t., upper slope, $\left(38^{\circ} 42^{\prime} \mathrm{N}\right.$ Lat, $0^{\circ} 11^{\prime} \mathrm{W}$ Long). Samples from same location.

BONN-1458. Red-brown Vertisol, Tapaiao de Ajuda, $3.8 \%$ C, Ap 10 to $21 \mathrm{~cm}$

BONN-1459. $1.4 \% \mathrm{C}, \mathrm{Bv} 35$ to $50 \mathrm{~cm}$

BONN-1460. $1.2 \%$ C, Bv 56 to $70 \mathrm{~cm}$
$470 \pm 70$ A.D. 1480

$1760 \pm 80$ A.D. 190

$2530 \pm 80$

580 B.C. 
BONN-1461. $0.9 \% \mathrm{C}, \mathrm{Bv} 77$ to $91 \mathrm{~cm}$

$$
\begin{aligned}
& 2580 \pm 100 \\
& 630 \text { в.C. }
\end{aligned}
$$

$3170 \pm 80$ 1220 B.c.

BONN-1462. $0.5 \%$ G, BC 98 to $106 \mathrm{~cm}$

$8900 \pm 170$

BONN-1463. $0.3 \%$ C, Cv 115 to $130 \mathrm{~cm}$

6950 B.C.

Samples coll. and subm. 1970 by W. Kerpen and H. Gewehr. Comment: most profiles are rather shallow and wholly within cracking zone, apparent mean residence times are low. Just the last red-brown Vertisol Tapaiao de Ajuda shows jump of age in $\mathrm{Cv}$ horizon, which probably lies outside normal depth of cracking.

\section{Australia}

The Australia series comprises 2 Gilgai sites with 1 mound and 1 depression profile each. Besides the framework of global Vertisol profile studies, comparison of apparent mean residence time vs. depth in profiles, on mounds and in depressions, was expected to reveal Vertisol dynamics, (Blackburn and Coppi, 1970).

Vertisol, Lillimur, Kaniva dist., Victoria, Gilgai mouncl, (36 $26^{\circ}$ $S$ Lat, $141^{\circ} 6^{\prime}$ E Long). Samples from same location.

BONN-1465. Vertisol, Lillimur, Gilgai mound, $3.2 \%$ C 0 to $10 \mathrm{~cm}$

$100.0 \pm 0.4 \%$
Modern

BONN-1466. $4.1 \% \mathrm{C}, 10$ to $20 \mathrm{~cm}$

$1130 \pm 70$ A.D. 820

BONN-1467. $3.4 \%$ C, 20 to $30 \mathrm{~cm}$

BONN-1468. $2.4 \%$ C, 30 to $40 \mathrm{~cm}$

BONN-I469. $1.8 \% \mathrm{C}, 40$ to $50 \mathrm{~cm}$

BONN-1470. $0.5 \%$ C, $501060 \mathrm{~cm}$

BONN-1471. $0.5 \% \mathrm{C}, 60$ to $70 \mathrm{~cm}$

BONN-I472. $0.5 \% \mathrm{C}, 70$ to $80 \mathrm{~cm}$

BONN-1473. $0.4 \% \mathrm{C}, 80$ to $90 \mathrm{~cm}$

BONN-1474. $0.3 \%$ C, 90 to $100 \mathrm{~cm}$
$1240 \pm 80$ A.D. 710

$$
2620 \pm 80
$$

670 B.C.

$2520 \pm 80$

570 B.c.

$2600 \pm 70$

650 is.c.

$2410 \pm 80$

460 B.C.

$2780 \pm 80$

830 s.c.

$4120 \pm 110$

2170 в.с.

$3800 \pm 140$

1850 B.C. 


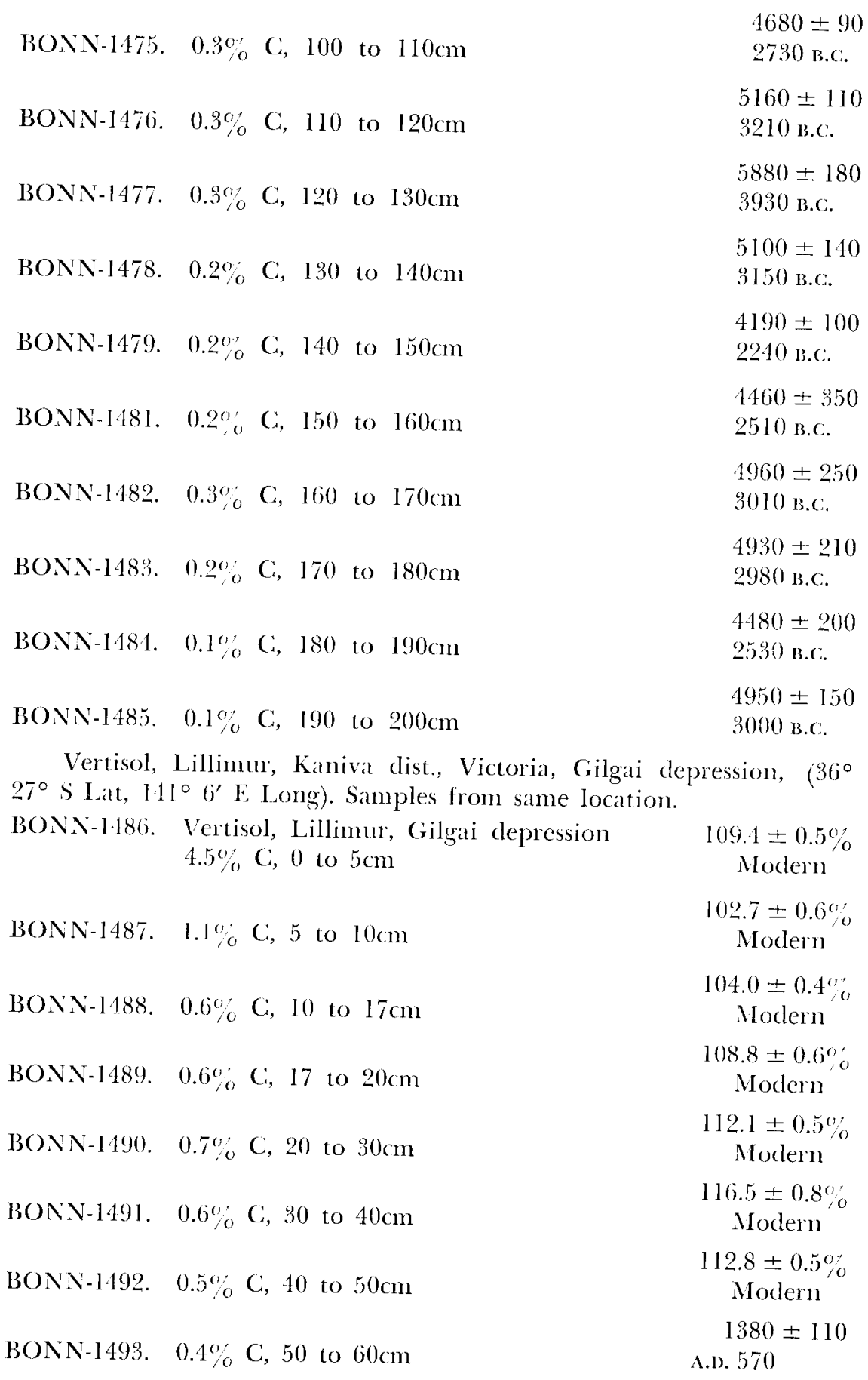


BONN-1494. $0.5 \% \mathrm{C}, 60$ to $70 \mathrm{~cm}$

BONN-1495. $0.3 \%$ C, 70 to $80 \mathrm{~cm}$

BONN-1496. $0.3 \%$ C, 80 to $90 \mathrm{~cm}$

BONN-1497. $0.3 \% \mathrm{C}, 90$ to $100 \mathrm{~cm}$

BONN-1498. $0.3 \% \mathrm{C}, 100$ to $110 \mathrm{~cm}$

BONN-1499, $0.3 \% \mathrm{C}, 110$ to $120 \mathrm{~cm}$

BONN-1501. $0.2 \% \mathrm{C}, 130$ to $140 \mathrm{~cm}$

BONN-1502. $0.1 \% \mathrm{C}, 140$ to $150 \mathrm{~cm}$

BONN-1503. $0.2 \%$ C, 150 to $160 \mathrm{~cm}$

BONN-1504. $0.2 \% \mathrm{C}, 160$ to $170 \mathrm{~cm}$

BONN-1505. $0.2 \%$ C, 170 to $180 \mathrm{~cm}$

BONN-1506. $0.2 \%$ C, 180 to $190 \mathrm{~cm}$

BONN-1507. $0.3 \% \mathrm{C}, 190$ to $200 \mathrm{~cm}$
$103.9 \pm 0.4 \%$

Modern

$1590 \pm 100$ A.D. 420

$2150 \pm 100$

200 B.C.

A.D. 1250

$700 \pm 120$

$590 \pm 80$

A.D. 1360

$1230 \pm 100$

A.1. 720

$1520 \pm 250$ A.D. 430

A.D. 1470

$$
480 \pm 80
$$

$390 \pm 250$

A.D. 1560

$690 \pm 280$

A.D. 1260

$1110 \pm 160$

A.D. 840

$2280 \pm 150$

390 B.C.

$1680 \pm 150$

A.D. 270

Vertisol, Miram, Kaniva dist., Victoria, Gilgai mound, $\left(36^{\circ} 28^{\prime} \mathrm{S}\right.$ Lat, $141^{\circ} 21^{\prime}$ E Long). Samples from same location.

BONN-1508. Vertisol, Miram, Gilgai mound,

$$
1.8 \% \mathrm{C}, 0 \text { to } 10 \mathrm{~cm}
$$

$119.9 \pm 0.4 \%$

Modern

BONN-1509. $0.9 \%$ C, 10 to $20 \mathrm{~cm}$

$107.9 \pm 0.5 \%$

Modern

BONN-1510. $0.5 \% \mathrm{C}, 20$ to $30 \mathrm{~cm}$

$104.8 \pm 0.6 \%$

Modern

BONN-1511. $0.6 \% \mathrm{C}, 30$ to $40 \mathrm{~cm}$

A.D. 1390

$$
560 \pm 90
$$

$710 \pm 70$

BONN-1512. $0.3 \%$ C, 40 to $50 \mathrm{~cm}$

A.D. 1240 


\begin{tabular}{|c|c|c|}
\hline BONN-1513. & $0.3 \% \mathrm{C}, 50$ to $60 \mathrm{~cm}$ & $\begin{array}{r}750 \pm 70 \\
\text { A.D. } 1200\end{array}$ \\
\hline BONN-1514. & $0.5 \% \mathrm{C}, 60$ to $70 \mathrm{~cm}$ & $\begin{array}{l}\quad 1610 \pm 70 \\
\text { A.D. } 340\end{array}$ \\
\hline BONN-1515. & $0.3 \% \mathrm{C}, 70$ to $80 \mathrm{~cm}$ & $\begin{array}{l}1110 \pm 100 \\
\text { A.D. } 840\end{array}$ \\
\hline BONN-1516. & $0.3 \%$ C, 80 to $90 \mathrm{~cm}$ & $\begin{array}{c}2100 \pm 80 \\
150 \text { в.с. }\end{array}$ \\
\hline BONN-1517. & $0.4 \% \mathrm{C}, 90$ to $100 \mathrm{~cm}$ & $\begin{array}{l}3110 \pm 120 \\
1160 \text { в.C. }\end{array}$ \\
\hline BONN-1518. & $0.3 \% \mathrm{C}, 100$ to $110 \mathrm{~cm}$ & $\begin{array}{l}3470 \pm 130 \\
1520 \text { B.C. }\end{array}$ \\
\hline BONN-1519. & $0.3 \% \mathrm{C}, \quad 110$ to $120 \mathrm{~cm}$ & $\begin{array}{l}4060 \pm 120 \\
2110 \text { B.C. }\end{array}$ \\
\hline BONN-1520. & $0.5 \%$ C, 120 to $130 \mathrm{~cm}$ & $\begin{array}{l}5170 \pm 130 \\
3220 \text { в.C. }\end{array}$ \\
\hline BONN-1521. & $0.3 \% \mathrm{C}, 130$ to $140 \mathrm{~cm}$ & $\begin{array}{l}5410 \pm 130 \\
3460 \text { в.C. }\end{array}$ \\
\hline BONN-1522. & $0.3 \% \mathrm{C}, 140$ to $150 \mathrm{~cm}$ & $\begin{array}{l}5940 \pm 160 \\
3990 \text { в.с. }\end{array}$ \\
\hline BONN-1523. & $0.2 \% \mathrm{C}, 150$ to $160 \mathrm{~cm}$ & $\begin{array}{l}5920 \pm 160 \\
3970 \text { в.C. }\end{array}$ \\
\hline BONN-1524. & $0.2 \% \mathrm{C}, 160$ to $170 \mathrm{~cm}$ & $\begin{array}{l}8050 \pm 160 \\
6110 \text { B.C. }\end{array}$ \\
\hline BONN-1525. & $0.2 \% \mathrm{C}, 170$ to $180 \mathrm{~cm}$ & $\begin{array}{l}8440 \pm 110 \\
6490 \text { в.C. }\end{array}$ \\
\hline BONN-1526. & $0.2 \% \mathrm{C}, 180$ to $190 \mathrm{~cm}$ & $\begin{array}{l}8140 \pm 180 \\
6190 \text { в.C. }\end{array}$ \\
\hline BONN-1527. & $0.2 \% \mathrm{C}, 190$ to $200 \mathrm{~cm}$ & $\begin{array}{l}8530 \pm 250 \\
6580 \text { в.C. }\end{array}$ \\
\hline
\end{tabular}

Vertisol, Miram, Kaniva dist., Victoria, Gilgai depression, $\left(36^{\circ} 28^{\prime}\right.$ $S$ Lat, $141^{\circ} 21^{\prime} \mathrm{E}$ Long). Samples from same location.

BONN-1528. Vertisol, Miram, Gilgai depression, $4.9 \% \mathrm{C}, 0$ to $5 \mathrm{~cm}$
$102.3 \pm 0.6 \%$ Modern

BONN-1529. $2.1 \%$ G, 5 to $10 \mathrm{~cm}$ $101.0 \pm 0.5 \%$ Modern

BONN-1530. $0.8 \%$ C, 10 to $20 \mathrm{~cm}$ $110.6 \pm 0.5 \%$ Modern 
BONN-1531. $0.9 \% \mathrm{C}, 20$ to $30 \mathrm{~cm}$

BONN-1532. $0.8 \% \mathrm{C}, 30$ to $40 \mathrm{~cm}$

BONN-1533. $0.5 \% \mathrm{C}, 40$ to $50 \mathrm{~cm}$

BONN-1534. $0.4 \% \mathrm{C}, 50$ to $60 \mathrm{~cm}$

BONN-1535. $0.4 \% \mathrm{C}, 60$ to $70 \mathrm{~cm}$

BONN-1536. $0.4 \% \mathrm{C}, 70$ to $80 \mathrm{~cm}$

BONN-1537. $0.3 \%$ C, 80 to $90 \mathrm{~cm}$

BONN-1538. $0.2 \%, \mathrm{C}, 90$ to $100 \mathrm{~cm}$

BONN-1539. $0.2 \%$ C, 100 to $110 \mathrm{~cm}$

BONN-1540. 0.2\% C, 110 to $120 \mathrm{~cm}$

BONN-1541. 0.2\% C, I20 to $130 \mathrm{~cm}$

BONN-1542. $0.2 \% \mathrm{C}, 130$ to $140 \mathrm{~cm}$

BONN-1543. $0.2 \% \mathrm{C}, 140$ to $150 \mathrm{~cm}$

BONN-1544. $0.2 \%$ C, 150 to $160 \mathrm{~cm}$

BONN-1545. $0.4 \% \mathrm{C}, 160$ to $170 \mathrm{~cm}$

BONN-1546. $0.2 \% \mathrm{C}, 170$ to $180 \mathrm{~cm}$

BONN-1547. 0.2\% C, 180 to $190 \mathrm{~cm}$

BONN-1548. $0.2 \%$ C, 190 to $200 \mathrm{~cm}$
$106.8 \pm 0.7 \%$

Modern

$101.1 \pm 0.4 \%$

Modern

$108.2 \pm 0.5 \%$

Modern

A.D. 1170

$780 \pm 80$

$810 \pm 70$

A.v. 1140

$1070 \pm 110$ A.D. 880

$3980 \pm 290$

1430 B.C.

$3660 \pm 140$

1710 B.C.

$3790 \pm 330$

1840 B.C.

$4750 \pm 320$

2800 B.C.

$4990 \pm 240$

3010 B.C.

$5300 \pm 260$

3350 B.c.

$5720 \pm 440$

3770 B.c.

$4880 \pm 320$

2930 B.C:

$6730 \pm 200$

4780 B.C.

$7540 \pm 390$ 5590 в.C.

$8390 \pm 400$ 6380 B.C.

$8450 \pm 260$ 6500 B.C. 
Samples coll. and subm. 1970 by G. Blackburn, CSIRO, Div. Soils, Adelaide. Comment: Gilgai Lillimur shows extremely different age vs. depth profiles on mounds and in depressions with lagging apparent mean residence time in the depression due to excessive deposits of surface material in dry-season cracks. Mound profile is also unusual in that 2 zones of almost homogenous apparent mean residence time are differentiated (30 to $80 \mathrm{~cm}$, ca. $2500 \mathrm{yr}, 80$ to $200 \mathrm{~cm}, \mathrm{ca} .4500$ to $5000 \mathrm{yr}$ ). In Gilgai Miram, apparent mean residence times are higher in mound and depression as well, up to $8500 \mathrm{yr}$. Mound and depression profiles both are to a level of $\mathrm{ca} .80 \mathrm{~cm}$, strongly intermixed with surface material, especially in the depression profile.

\section{Germany}

Fossil Al, Elserspoint, $10 \mathrm{~km}$ W Freising, $100 \mathrm{~cm}$ under loess-loam (eroded Hapludalf). Time of chernozem formation in Bavaria is questioned $\left(48^{\circ} 30^{\prime} \mathrm{N}\right.$ Lat, $11^{\circ} 40^{\prime} \mathrm{E}$ Long).

\section{BONN-1464.}

$6160 \pm 90$

Fossil A-Horizon, Exerspoint, $2.6 \%$ C, $100 \mathrm{~cm}$. Sample coll. and subm. 1971 by U. Schwertmann, Inst. Bodenkunde, Techn. Univ. Munich. Comment: result agrees well with apparent mean resiclence time found in AC transition zone of recent chernozem profiles in other parts of Germany (Scharpenseel, I972).

Fossil A horizon, and charcoal in terrace brown earth, $5 \mathrm{~km} S$ Siegenburg, Abens valley, $\mathrm{N}$ Bacaria, $\left(48^{\circ} 46^{\prime} \mathrm{N}\right.$ Lat, I ${ }^{\circ} 50^{\prime} \mathrm{E}$ Long). Samples from same location.

BONN-1648.

$2270 \pm 70$

320 в.c.

Fossil A-horizon, terrace Abens valley, Siegenburg, 60 to $80 \mathrm{~cm}$.

\section{BONN-1649.}

Charcoal fireplace, Im $\phi$.

\section{BONN-16.51.}

Charcoal from different fireplace, $150 \mathrm{~cm}$ below sand blanket. Samples Coll. and subm. 1971 by U. Schwertmann. Comment: dates alluviation of material embedding fossil A-horizon and fireplaces.

Humus horizons in high flood loam, Hapludalf, on nether terrace of Rhine R., gravel pit Horn, Bonn-Hersel, (50 $43^{\prime} \mathrm{N}$ Lat, $7^{\circ} 8^{\prime} \mathrm{E}$ Long).

\section{BONN-1652.}

$5080 \pm 110$ $100 \mathrm{~cm}$.

$$
\begin{array}{r}
1220 \pm 80 \\
\text { A.D. } 730
\end{array}
$$

$$
1460 \pm 70
$$

\section{B.C.}

Hapludalf in high flood loam on nether terrace, $0.5 \% \mathrm{C}, \mathrm{Bt} 60$ to 


\section{BONN-1653.} $180 \mathrm{~cm}$.

fA-horizon below Hapludalf, same location, $0.4 \%$ C, fA 160 to

Samples coll. and subm. 1972 by Chr. Haupenthal, Inst. Bodenkunde, Bonn Univ. Comment: date of Bt horizon is minimum for recent Hapludalf, date of fA horizon indicates 1 st soil development on nether terrace, showing good agreement with expectation due to terrace history.

Carbonaceous, bituminous coating of gravel remnant in younger terrace of Isar, Ascholding, Wolfratshausener Becken, $\left(47^{\circ} 5 \mathrm{I}^{\prime} \mathrm{N}\right.$ Lat, $11^{\circ} 28^{\prime}$ E Long).

\section{BONN-1657.}

$28,320 \pm 470$ 26,370 в.C.

Carbonaceous, bituminous coating on gravel relic, $280 \mathrm{~cm}$. Sample coll. and subm. 1971 by W. Kerpen, Chr. Haupenthal, and H. W. Scharpenseel. Comment: terrace thought to be late Pleistocene, most likely Holocene in origin (Dietz, 1971). Old date difficult to interpret. Secondary quartz crystallization adjacent and partly covering $\mathrm{C}$ material. Gravel relic is void of $\mathrm{CaCO}_{3}$ in otherwise calcareous milieu and rounded by water transport. Conflicting views on terrace chronology make clate controversial, confirmed by repetition.

Brownearth of unusually high and deep organic matter, meadow on Würm basal moraine of Isar foreland glacier, Unterbuchen, $\left(11^{\circ} 30^{\prime}\right.$ $\mathrm{N}$ Lat, $47^{\circ} 42^{\prime} \mathrm{E}$ Long). Soil suspected of amelioration by plaggen (swards). Existence and time of plaggen management in Bavarian Alps foreland is of interest.

\section{BONN-1669.}

$1090 \pm 70$

Brownearth, humus to great depth on basal moraine, $4.4 \% \mathrm{C}$, Ahl 20 to $30 \mathrm{~cm}$. Samples from same location.

BONN-1670.

$2.8 \% \mathrm{C}, \mathrm{Ah} 230$ to $40 \mathrm{~cm}$

\section{BONN-1671.}

$2.5 \% \mathrm{C}, \mathrm{Ah} 340$ to $50 \mathrm{~cm}$

\section{BONN-1672.}

$2.5 \% \mathrm{C}, \mathrm{Ah} 450$ to $60 \mathrm{~cm}$

Samples coll. and subm. 1972 by H. Jert7, Bayr. Geol. Landesamt, Munich. Comment: dates are older than corresponding results on plaggen soils in NW Germany and Ireland (Mückenhausen et al., 1968, Scharpenseel, 1972). Micromorphologic studies on thin sections should decide nature of plaggen soil.

\section{$1630 \pm 70$ \\ A.D. 320 \\ $2350 \pm 80$ \\ 400 B.C.}

$3800 \pm 80$

1850 B.C. 
Roots and fossil A horizon from gravel pit, Gemeinde Trieb, Oberfranken, Bavaria, (50 $0^{\circ} \mathrm{N}$ Lat, $11^{\circ} 8^{\prime} \mathrm{E}$ Long). Samples serve stratigraphic study of terraces in upper Main valley.

\section{BONN-1700.}

Root, gravel pit Maintag, Trieb 170 to $145 \mathrm{~cm}$.

\section{BONN-1801.}

Ah horizon, pit Maintag, 180 to $200 \mathrm{~cm}$.

\section{BONN-1802.}

Root, vertical in sediment, 200 to $270 \mathrm{~cm}$ Samples coll. 1972 by sumples coll. and subm. 1972 by W. Schirmer, Geol. Inst., Univ. Cologne. Comment: dates, estimated to be Sub-Atlantic, are older and require new approach.

Fossil loessic A horizon, covered by Pleistocene terrace material, Kärlich, mining pit, $\left(50^{\circ} 26^{\prime} \mathrm{N}\right.$ Lat, $7^{\circ} 30^{\prime} \mathrm{E}$ Long).

\section{BONN-1659.}

$30,450 \pm 1270$

Humus containing soil, Kärlich, $2.6 \%$ C. Coll. and subm. 1972 by J. Frechen, Inst. Petrol., Bonn Univ. Comment: date confirms expectation, contemporaneous with Paudorl interstadial.

Humus containing silty $A$ horizon, sandwiched by loess material, underlying tuffaceous material, probably of Rodderberg volcanism. $N$ slope Bausenberg, Lengsdorf, $140 \mathrm{~m}$ above NN, $\left(50^{\circ} 42.5^{\prime} \mathrm{N}\right.$ Lat $7^{\circ} 2^{\prime}$ E Long). Dated to determine age of Rodderberg volcanism, Quaternary profile of Bonn area.

\section{BONN.1699.}

Humus containing horizon, silty, Lengsdorf, $400 \mathrm{~cm}$ deep. Coll. and subm. 1972 by G. Bartels, Geogr. Inst., Univ. Bonn. Comment: date lags behind expected age: $>30,000 \mathrm{yr}$. Thorough study of existence of rejuvenating principles, such as small roots, will follow.

Fossil A horizon in gravelly gley, Gammelsbach valley, N Eberbach, buntsandstone Odenwald, $\left(49^{\circ} 29^{\prime} \mathrm{N}\right.$ Lat, $8^{\circ} 57^{\prime} \mathrm{E}$ Long). Date of fossil $A$ is taken to estimate sedimentation speed of younger accumulations on top.

\section{BONN-1815.}

$$
1350 \pm 110
$$

\section{A.D. 600}

Gleyey fAh, Gammelsbach valley, Eberbach, Odenwald, $3.0 \%$ C. Coll. and subm. 1972 by E. Szabados, Inst. Bodenkunde, Techn. Univ. Berlin. Comment: estimates were either Boreal age or pre-medieval deforestation. Results confirm latter. 
III. SOIL ORGANIC MATTER FRACTIONS

Soil organic matter fractions were dated after different pretreatments of the soil samples.

\section{A. Particle size}

Similar to particle size dating on Inden parabrowncarth (R., 1971, v. 13, p. 207; Scharpenseel, 1970), texture fractions of a fossil A horizon, underlying trachyt tuff of Alleröd volcanism, were dated, compared to charcoal from same horizon. Niedermendig, tephrit quarry Michels, $\left(50^{\circ} 26^{\prime} \mathrm{N}\right.$ Lat, $7^{\circ} 15^{\prime} \mathrm{E}$ Long). Material belongs to same fossil horizon as BONN-413, (R., 1970, v. 12, p. 27).

\section{BONN-1681.}

$$
\begin{gathered}
11,550 \pm 160 \\
9600 \text { B.C. }
\end{gathered}
$$

Fossil A horizon, Niedermendig, charcoal, 300 to $350 \mathrm{~cm}$.

\section{BONN-1682.}

Same location, particle size fraction $>0.2 \mathrm{~mm}, 0.86 \% \mathrm{C}$.

\section{BONN-1684.}

$10,950 \pm 150$ 9000 B.C.

Same location, particle size fraction 63 to $2 \mu, 0.68 \%$ C.

Samples coll., fractioned, and synthesized 1972 by Cinr. Haupenthal, Inst. Bodenkunde, Bonn Univ. Comment: between charcoal and organic C fraction, particle size 63 to $2 \mu$, agreement is rather good. Exclusive use of larger particle fraction leads to drastic decrease of age. Particle size fractions 60 to $l_{\mu}$ seem optimal in loessic soils (Scharpenseel, 1970; 1972).

\section{B. Fractions from continuous extraction}

One chernozem and podzol each were continuously extracted by 0.15 $\mathrm{M} \mathrm{Na} \mathrm{P}_{2} \mathrm{O}_{\tau}$ solution (chernozem requircd pretreatment with $0.1 \mathrm{~N}$ $\mathrm{H}_{2} \mathrm{SO}_{4}$ ). Successive fractions of extracted humic acids wcre separately dated, after acid precipitation and drying of humic acids.

BONN-1809.

$1030 \pm 100$ A.D. 920

Chernozem, Aseler Holz, 22.5\% C, AC 40 to $60 \mathrm{~cm},\left(52^{\circ} 10^{\prime} \mathrm{N}\right.$ Lat, $10^{\circ} 1^{\prime}$ E Long), 1. fraction.

\section{BONN-1810.}

$4130 \pm 270$

Same location, $36.3 \%$ C, 2, fraction.

2180 B.C.

\section{BONN-1811.}

$4970 \pm 80$

Same location, $1.05 \% \mathrm{C}$, whole sample, unfractioned.

Samples coll., extracted, and subm. 1972 by Chr. Haupenthal. Comment: preceding 1 st extract sample of low $\mathrm{C}$ concentration was modern. Alkali extract of hard-to-extract soils is highly susceptible to atmospheric 
bomb $\mathrm{C}$ contamination, even if work was performed, wherever possible, under $\mathrm{N}_{2}$ gas. In the BONN lab., this method was rejected.

BONN-1688. Podzol Scherpenseel, gravel pit Weber, $22.5 \%$ C, Bh 120 to $140 \mathrm{~cm}$,

$1400 \pm 140$

$\left(50^{\circ} 56^{\prime} \mathrm{N}\right.$ Lat, $6^{\circ} 0.5^{\prime} \mathrm{E}$ Long).

A.D. 550

Samples are from same location.

BONN-1689. $24.8 \% \mathrm{C}$

$1160 \pm 70$

A.D. 790

BONN-1691. 27.0\% C

$1460 \pm 80$

A.D. 490

BONN-1692. $25.5 \% \mathrm{C}$

$1950 \pm 110$

BONN-1693. 24.0\% C

A.D. 600

BONN-1697. Podrol Scherpenseel, gravel pit Weber, $20.8 \%$ C, Ah 80 to $100 \mathrm{~cm}$

$$
1510 \pm 130
$$

A.D. 440

$$
\begin{aligned}
& 1290 \pm 70 \\
& \text { A.D. } 660
\end{aligned}
$$

$1220 \pm 70$

BONN-1698. Same location, $16.5 \% \mathrm{C}$

A.D. 730

Samples coll., extracted, and subm. 1972 by Chr. Haupenthal. Comment: extraction of humus-C from podzols proceeds quickly and efficiently, yielding large quantities of organic carbon till gray-white sand remains. Danger of contamination is lower than in case of chernozem due to much shorter exposure time required for phase of alkali extraction. Results do not favor taking one special fraction out of continuous extraction.

IV. SUBHYDRIC SOILS, GYTTJA

\section{A. Schalkenmehren}

Gyttja in Schalkenmehren-Maar, Eifel. Continuation of BONN-781 -802, Profile III (R., 1971, v. 12, p. 207). Profiles I to $V$ are part of larger program of subhydric soil studies in Eifel Maaren. The origin of Schalkenmehren Maar, a true gas explosion funnel of ca. $25 \mathrm{~m}$ depth, was lately palynologically dated to ca. 10,950 в.r., by $\mathrm{C}^{14}$ dating of adjacent dry maar layers to 13,900 B.P. (Erlenkäuser et al., 1970). Erlenkäuser and co-workers estimate that, based on stable isotope measurements, mud of Eifel maars might be contaminated by magmatic $\mathrm{CO}_{2}$, which could account for ca. $2000 \mathrm{yr}$ gap between palynologic and $\mathrm{C}^{14}$ dates. Samples are taken with a case lot, $\left(50^{\circ} 11.5^{\prime} \mathrm{N}\right.$ Lat, $6^{\circ} 50^{\prime} \mathrm{E}$ Long).

BONN-994. Schalkenmehren maar, Profile I, NE of maar, $4690 \pm 90$ taken by case lot, $20.0 \%$ C, 0 to $10 \mathrm{~cm}$. 2740 B.C. Samples from same location. 
BONN-995. $24.0 \% \mathrm{C}, 10$ to $20 \mathrm{~cm}$

BONN-996. $18.4 \% \mathrm{C}, 20$ to $30 \mathrm{~cm}$

BONN-997. $23.5 \% \mathrm{C}, 30$ to $40 \mathrm{~cm}$

BONN-998. $30.6 \%$ C, 40 to $50 \mathrm{~cm}$

BONN-999. $31.9 \% \mathrm{C}, 50$ to $60 \mathrm{~cm}$

BONN-1000. $17.5 \% \mathrm{C}, 60$ to $70 \mathrm{~cm}$

BONN-1001. $26.9 \%$ C, 70 to $80 \mathrm{~cm}$

BONN-1002. $27.0 \% \mathrm{C}, 80$ to $90 \mathrm{~cm}$

BONN-1003. 27.5\% C, 90 to $100 \mathrm{~cm}$

BONN-1004. 26.6\% C, 100 to $110 \mathrm{~cm}$

BONN-1005. 20.0\% C, 110 to $120 \mathrm{~cm}$

BONN-1662. $25.5 \% \mathrm{C}, 120$ to $150 \mathrm{~cm}$

BONN-1007. Schalkenmehren maar, Profile II, $\mathrm{E}$ of maar, taken by case lot, $6.8 \% \mathrm{C}$, 0 to $20 \mathrm{~cm}$. Samples from same location.

BONN-1008, $4.9 \% \mathrm{C}, 20$ to $30 \mathrm{~cm}$

BONN-1009. $4.6 \%$ C, 30 to $40 \mathrm{~cm}$

BONN-1010. $4.2 \%$ C, 40 to $50 \mathrm{~cm}$

BONN-1011. $5.7 \% \mathrm{C}, 50$ to $60 \mathrm{~cm}$

BONN-I012. $6.0 \%$ C, 60 to $70 \mathrm{~cm}$
$4790 \pm 70$

2840 B.C.

$5240 \pm 80$

3290 в.C.

$5340 \pm 90$

3390 в.C.

$7260 \pm 130$

5310 B.C.

$7170 \pm 110$

5220 B.C.

$9220 \pm 130$

7270 в.с.

$8480 \pm 140$

6530 B.C.

$9740 \pm 110$

7790 в.с.

$9910 \pm 100$

7960 в.с.

$9800 \pm 90$

7850 в.C.

$12,130 \pm 140$

10,180 в.с.

$12,190 \pm 170$

10,240 B.C.

$3470 \pm 70$

1520 B.C.

$3300 \pm 100$

1350 B.C.

$3580 \pm 90$

1630 B.C.

$2660 \pm 90$

710 в.c.

$3220 \pm 80$

1270 B.C.

$4020 \pm 80$

2070 в.C. 
BONN-1013. $5.0 \% \mathrm{C}, 70$ to $80 \mathrm{~cm}$

BONN-1014. $4.3 \%$ C, 80 to $90 \mathrm{~cm}$

BONN-1015. $3.4 \%$ C, 90 to $100 \mathrm{~cm}$

BONN-1016. $5.3 \%$ C, 100 to $110 \mathrm{~cm}$

BONN-1017. $6.9 \%$ C, 110 to $120 \mathrm{~cm}$

BONN-1018. $8.5 \%$ C, 120 to $130 \mathrm{~cm}$

BONN-1019. $14.4 \% \mathrm{C}, 130$ to $140 \mathrm{~cm}$

BONN-1020. $14.3 \% \mathrm{C}, 140$ to $150 \mathrm{~cm}$

BONN-1021. $6.0 \%$ C, 150 to $160 \mathrm{~cm}$

BONN-1022. I $13.5 \%$ C, 160 to $167 \mathrm{~cm}$

BONN-1023. $8.3 \% \mathrm{C}, 167$ to $170 \mathrm{~cm}$

BONN-1024. $15.3 \%$ C, 170 to $185 \mathrm{~cm}$

BONN-1025. 20.6\% C, 185 to $200 \mathrm{~cm}$

BONN-1026. Schalkenmehren maar, Profile IV, $\mathrm{N}$ of maar, taken by case lot, $6.6 \% \mathrm{C}$ 0 to $10 \mathrm{~cm}$. Samples from same location.

BONN-1027. $4.8 \% \mathrm{C}, 10$ to $20 \mathrm{~cm}$

BONN-1028. $4.6 \% \mathrm{C}, 20$ to $30 \mathrm{~cm}$

BONN-1029. $6.5 \%$ C, 30 to $40 \mathrm{~cm}$

BONN-1030. $\quad 6.0 \%$ C, 40 to $50 \mathrm{~cm}$
$4750 \pm 80$

2800 B.C.

$3200 \pm 80$

1250 в.C.

$3120 \pm 80$

1170 B.C.

$3290 \pm 80$

1340 в.c.

$3570 \pm 80$

1620 B.C.

$3740 \pm 70$

1790 в.с.

$3340 \pm 80$

1890 B.C.

$4930 \pm 90$

2980 B.C.

$4770 \pm 90$

2820 в.с.

$5200 \pm 80$

3250 B.C.

$8930 \pm 100$

6980 в.C.

$11,060 \pm 150$

9110 в.C.

$12,160 \pm 130$

10,210 B.c.

$3160 \pm 70$

1210 B.C.

$2940 \pm 70$

990 B.C.

$2790 \pm 70$

840 B.c.

$2470 \pm 80$

520 в.с.

$3960 \pm 60$

2010 B.c. 
BONN-1031. $7.6 \%$ C, 50 to $60 \mathrm{~cm}$

BONN-1032. $5.7 \% \mathrm{C}, 60$ to $70 \mathrm{~cm}$

BONN-1033. $9.8 \% \mathrm{C}, 70$ to $80 \mathrm{~cm}$

BONN-1034. $3.8 \%$ C, 80 to $90 \mathrm{~cm}$

BONN-1036. $5.8 \% \mathrm{C}, 100$ to $110 \mathrm{~cm}$

BONN-1037. $6.3 \% \mathrm{C}, 110$ to $120 \mathrm{~cm}$

BONN-1038. $6.7 \% \mathrm{C}, 120$ to $130 \mathrm{~cm}$

BONN-1039. $13.1 \%$ C, 130 to $140 \mathrm{~cm}$

BONN-1040. $13.5 \%$ C, 140 to $150 \mathrm{~cm}$

BONN-1041. $18.3 \%$ C, 150 to $160 \mathrm{~cm}$

BONN-1043. $19.5 \%$ C, 170 to $180 \mathrm{~cm}$

BONN-1044. $17.7 \% \mathrm{G}, 180$ to $190 \mathrm{~cm}$

BONN-1045. $12.8 \%$ C, 190 to $200 \mathrm{~cm}$

BONN-1046. Schalkenmehren maar, Profile V, SW of maar, taken by case lot, $8.3 \% \mathrm{C}$, 0 to $10 \mathrm{~cm}$. Samples from same location.

BONN-1047. $2.8 \% \mathrm{C}, 10$ to $20 \mathrm{~cm}$

BONN-1048. $4.3 \%$ C, 20 to $30 \mathrm{~cm}$

BONN-1049. $4.5 \% \mathrm{C}, 30$ to $40 \mathrm{~cm}$

BONN-1050. $4.9 \%$ C, 40 to $50 \mathrm{~cm}$
$3580 \pm 60$

1630 в.C.

$3520 \pm 70$

1570 в.C.

$3390 \pm 60$

1440 в.C.

$3060 \pm 60$

1110 B.C.

$2630 \pm 60$ 680 B.c.

$3000 \pm 70$

1050 B.C.

$2930 \pm 70$

980 B.c.

$2930 \pm 60$ 980 B.C.

$3020 \pm 60$

1070 B.c.

$3220 \pm 60$

1270 B.c.

$3110 \pm 70$

1160 s.c.

$3270 \pm 70$

1320 в.с.

$9290 \pm 130$

7340 в.C.

$3450 \pm 80$

I500 B.C.

$2800 \pm 80$

850 B.C.

$2770 \pm 90$

820 в.C.

$3680 \pm 80$

1730 в.c.

$3840 \pm 80$

1890 B.C. 
BONN-1051. $4.4 \% \mathrm{C}, 50$ to $60 \mathrm{~cm}$

BONN-1052. $3.6 \% \mathrm{C}, 60$ to $70 \mathrm{~cm}$

BONN-1053. $2.3 \% \mathrm{C}, 70$ to $80 \mathrm{~cm}$

BONN-1054. $8.1 \%$ C, 80 to $90 \mathrm{~cm}$

BONN-1055. $2.8 \% \mathrm{C}, 90$ to $100 \mathrm{~cm}$

BONN-1056. $3.0 \% \mathrm{C}, 100$ to $110 \mathrm{~cm}$

BONN-1057. 5.0\% C, 110 to $120 \mathrm{~cm}$

BONN-1058. 4.0\% C, 120 to $130 \mathrm{~cm}$

BONN-1059. $12.0 \% \mathrm{C}, 130$ to $140 \mathrm{~cm}$

BONN-1060. $14.5 \% \mathrm{C}, 140$ to $150 \mathrm{~cm}$

BONV-1061. 19.2\% C, 150 to $160 \mathrm{~cm}$

BONN-1062. $19.9 \%$ C, 160 to $170 \mathrm{~cm}$

BONN-1063. $30.0 \% \mathrm{C}, 170$ to $180 \mathrm{~cm}$

BONN-1064. $20.8 \%$ C, 180 to $190 \mathrm{~cm}$

BONN-1065. $20.8 \%$ C, 190 to $200 \mathrm{~cm}$
$3580 \pm 80$ 1630 B.C.

$2710 \pm 80$

760 B.C.

$3000 \pm 80$ 1050 B.C.

$2980 \pm 80$ 1030 B.C.

$3090 \pm 70$

1140 B.C.

$2920 \pm 80$

979 B.C.

$2950 \pm 80$ 1000 B.C.

$2920 \pm 100$

970 B.C.

$3340 \pm 80$

1390 B.C.

$2850 \pm 80$

900 B.C.

$2510 \pm 80$

560 B.C.

$2350 \pm 70$

400 B.C.

$2800 \pm 80$

850 B.C.

$2630 \pm 80$

680 B.C.

$2670 \pm 80$

720 B.C.

Samples coll. and subm. 1969 by H. W. Scharpenseel, W. Kerpen, and H. Gewehr, Inst. Bodenkunde, Bonn Univ. Comment: dependent on location of sampling, age vs. depth progression is very different, sometimes even to the point of trend reversal. Also, the mixing effect with rejuvenation to considerable depth, e.g. by inflowing sewage or methane bubbles, is assoc. with site of sampling spot, distance as well as windward direction from lake shore village. C concentrations of gyttja vary greatly with location and depth. Highest dates in Profile I and II, which were 
ending on top of tuffaceous sand, blocking further penetration of the case lot, reach ca. $12,000 \mathrm{yr}$. Profile $I V$ is intermediate, dates of Profiles III and IV, near inhabited S lake shore are much lower. Apparently, Erlenkäuser et al. (1970), besides using dry maar samples, disposed of cores, penetrating also through the sandy tuff layers, which could account for $1600 \mathrm{yr}$ more, compared with our deepest samples. Results show danger of lake sediment dating, relying on too few sampling spots.

\section{B. Selent}

Gyttja in lake of Selent, E Holsteen. Continuation of BONN-882 -908, Profile II (R., 1971, v. 13, p. 209). In this second biggest glacier lake of $\mathrm{E}$ Holsteen, with max. depth ca. $45 \mathrm{~m}$, thickness of mud sediment varies with echo sounder between $<1 \mathrm{~m}$ and 5 to $10 \mathrm{~m}$. Thickest sediment corresponds with shallow water in $\mathbf{E}$ part of lake. Profile cores were taken by means of case lot (Profiles I, III, IV), as well as with Livingstone borer (Profiles II, V, VI) (54 $41^{\prime} \mathrm{N}$ Lat, $10^{\circ} 35^{\prime} \mathrm{E}$ Long).

BONN-869. Selent lake, Profile I, in front of Gickau, taken by case lot, $11.8 \% \mathrm{C}, 0$ to $25 \mathrm{~cm}$. Samples from same location.

BONN-871. $12.3 \%$ C, 25 to $35 \mathrm{~cm}$

BONN-873. $12.7 \%$ C, 45 to $55 \mathrm{~cm}$

BONN-874. $15.9 \%$ C, $551065 \mathrm{~cm}$

BONN-875. $22.3 \%$ C, 65 to $75 \mathrm{~cm}$

BONN-876. $17.5 \%$ C, 75 to $85 \mathrm{~cm}$

BONN-877. $19.5 \% \mathrm{C}, 85$ to $100 \mathrm{~cm}$

BONN-878. $19.9 \% \mathrm{C}, 100$ to $115 \mathrm{~cm}$

BONN-879. $14.6 \% \mathrm{C}, 115$ to $125 \mathrm{~cm}$

BONN-880, Tube sample, $2 \mathrm{~m}$ below end of case lot, underneath sand, $3.7 \% \mathrm{C}$.

BONN-1122. Soil profile on shore, opposite Profile I in front of Giekau, $6 \% \mathrm{C}$, Ahl 10 to $25 \mathrm{~cm}$. Samples from same location.
A.D. 1570

$$
380 \pm 70
$$

$500 \pm 70$

A.D. 1450

$450 \pm 70$

A.D. 1500

$$
1670 \pm 100
$$

A.D. 280

A.D. 1250

$$
700 \pm 70
$$

$$
790 \pm 80
$$

A.D. 1160

$$
970 \pm 70
$$

A.D. 980

A.D. 1020

$$
930 \pm 70
$$

$$
1190 \pm 70
$$

A.D. 760

$10,170 \pm 140$ 8220 B.C.

A.D. 1810
$140 \pm 60$ 


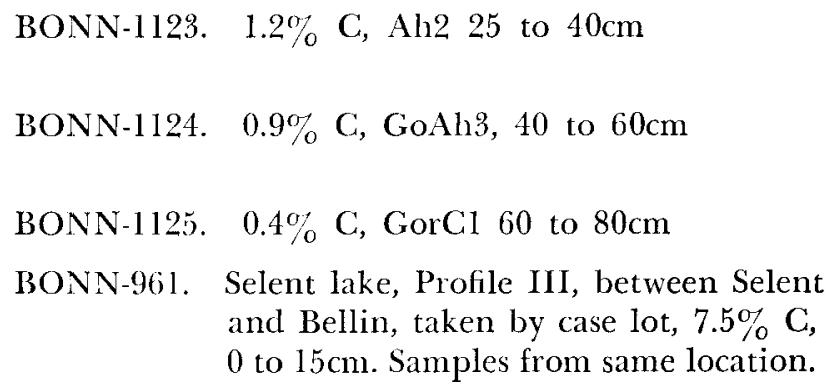
and Bellin, taken by case lot, $7.5 \% \mathrm{C}$, 0 to $15 \mathrm{~cm}$. Samples from same location.

BONN-962. $18.5 \% \quad \mathrm{C}, 10$ to $15 \mathrm{~cm}$

BONN-911. $4.9 \% \mathrm{C}, 15$ to $20 \mathrm{~cm}$

BONN-912. $5.3 \%$ C, 20 to $30 \mathrm{~cm}$

BONN-913. $6.4 \% \mathrm{C}, 30$ to $40 \mathrm{~cm}$

BONN-914. $6.4 \% \mathrm{C}, 40$ to $50 \mathrm{~cm}$

BONN $-915.7 .1 \% \mathrm{C}, 50$ to $55 \mathrm{~cm}$

BONN-916. $2.8 \% \quad \mathrm{C}, 55$ to $60 \mathrm{~cm}$

BONN-917. $2.3 \%$ C, 60 to $70 \mathrm{~cm}$

BONN-918. $2.1 \% \mathrm{C}, 70$ to $80 \mathrm{~cm}$

BONN-919. $0.9 \% \mathrm{C}, 80$ to $90 \mathrm{~cm}$

BONN-920. $1.0 \% \mathrm{C}, 90$ to $100 \mathrm{~cm}$

BONN-921. $0.5 \% \mathrm{C}, 100$ to $110 \mathrm{~cm}$

BONN-922. $0.4 \% \mathrm{C}, 110$ to $120 \mathrm{~cm}$

BONN-924. $0.9 \% \mathrm{C}, 130$ to $140 \mathrm{~cm}$
$390 \pm 60$

A.D. 1560

$620 \pm 60$

A.D. 1330

$1400 \pm 70$

A.D. 550

$1290 \pm 70$ A.D. 660

$$
1300 \pm 70
$$

A.D. 650

$1910 \pm 100$ A.D. 40

$1430 \pm 100$ A.D. 520

$2360 \pm 80$ 410 B.C.

$3830 \pm 80$ I 880 B.C.

$6380 \pm 100$ 4430 B.C.

$6660 \pm 100$ 4710 B.C.

$9760 \pm 130$ 7810 B.C.

$11,350 \pm 150$ 9400 B.C.

$11,520 \pm 130$ 9570 в.С.

$9930 \pm 120$ 7980 B.C.

$13,050 \pm 420$ 11,100 B.C.

$12,570 \pm 440$ 10,620 B.C.

$15,200 \pm 260$ 13,250 B.C. 
BONN-925. $\quad 0.5 \%, \mathrm{C}, 140$ to $150 \mathrm{~cm}$

BONN-926. $0.5 \% \quad \mathrm{G}, 150$ to $160 \mathrm{~cm}$

BONN-927. $0.8 \% \mathrm{C}, 160$ to $170 \mathrm{~cm}$

BONN-930. $0.8 \% \quad C, 190$ to $200 \mathrm{~cm}$

BONN-931. $0.5 \%$ C, 200 to $210 \mathrm{~cm}$

BONN-932. $0.8 \% \quad \mathrm{C}, 210$ to $220 \mathrm{~cm}$

BONN-963. $0.5 \% \quad \mathrm{C}, 220$ to $240 \mathrm{~cm}$

BONN-964. $1.4 \%$ C, 240 to $250 \mathrm{~cm}$

BONN-933. Selent lake, Profile IV, in front of beach of Selent village, taken by case lot, $14.6 \%$ C, 0 to $5 \mathrm{~cm}$. Samples from same location.

BONN-934. $12.5 \%$ C, 5 to $10 \mathrm{~cm}$

BONN-935. $9.5 \% \mathrm{C}, 10$ to $20 \mathrm{~cm}$

BONN-936. $10.9 \%, C, 20$ to $30 \mathrm{~cm}$

BONN-937. $10.1 \%$ C, 30 to $40 \mathrm{~cm}$

BONN-998. $14.3 \% \mathrm{C}, 10$ to $50 \mathrm{~cm}$

BONN-939. $10.9 \% \mathrm{C}, 50$ to $60 \mathrm{~cm}$

BONN-940. $11.3 \% \mathrm{C}, 60$ to $70 \mathrm{~cm}$

BONN-941. $11.1 \% \mathrm{C}, 50$ to $70 \mathrm{~cm}$ (rep)

BONN-942. $11.0 \% \mathrm{C}, 70$ to $80 \mathrm{~cm}$
$11,020 \pm 160$ 9070 B.C.

$21,640 \pm 550$ 19,690 B.C.

$21,200 \pm 550$ 19,250 в.C.

$20,510 \pm 460$ 18,560 B.C.

$23,890 \pm 700$ 21,940 B.C.

$24,410 \pm 630$ 22,460 B.C.

$24,790 \pm 800$ 22,840 B.C.

$24,830 \pm 970$ 22,880 B.C.

$$
1630 \pm 70
$$
A.D. 320

A.D. 1030

$$
920 \pm 80
$$

$1550 \pm 70$ A.D. 400

$$
1220 \pm 70
$$

A.D. 730

$1050 \pm 70$ A.D. 900

$1150 \pm 70$ A.v. 800

$1090 \pm 70$ A.D. 860

$1040 \pm 80$ A.D. 950

$1080 \pm 70$ A.D. 870

$1160 \pm 70$ A.D. 790 
BONN-943. $10.5 \%$ C, 80 to $90 \mathrm{~cm}$

BONN-944. $11.4 \%$ C, 80 to $100 \mathrm{~cm}$ (rep)

BONN-945. $9.0 \%$ C, 90 to $100 \mathrm{~cm}$

BONN-946. $8.5 \% \mathrm{C}, 100$ to $110 \mathrm{~cm}$

BON N-948. $8.6 \%$ C, 110 to $120 \mathrm{~cm}$

BONN-949. $10.5 \% \mathrm{C}, 120$ to $130 \mathrm{~cm}$

BONN-951. $10.5 \%$ C, 130 to $144 \mathrm{~cm}$

BONN-952, 5.4\% C, 144 to $154 \mathrm{~cm}$

BONN-953. $8.0 \%$ C, 154 to $157 \mathrm{~cm}$

BONN-954. 4.4\% C, 157 to $160 \mathrm{~cm}$

BONN-955. $0.8 \% \mathrm{C}, 160$ to $170 \mathrm{~cm}$

BONN-956. $1.8 \% \mathrm{C}, 170$ to $180 \mathrm{~cm}$

BONN-957. $0.5 \%$ C, 180 to $190 \mathrm{~cm}$

BONN-959. $0.3 \%$ C, 190 to $215 \mathrm{~cm}$

BONN-1I27. Soil profile on shore, opposite Profile IV, in front of beach, Sclent village, peaty, $36.4 \% \mathrm{C}, \mathrm{I} 110$ to $30 \mathrm{~cm}$. Samples from same location.

BONN-1128. 41.3\% C, I2 30 to $50 \mathrm{~cm}$

BONN-1129. 35.6\% C, T3 40 to $60 \mathrm{~cm}$

BONN-1130. $34.1 \%$ C, T4 60 to $80 \mathrm{~cm}$
$1770 \pm 70$

A.D. 180

$1670 \pm 220$ A.D. 280

$1780 \pm 70$ A.D. 170

$2060 \pm 70$

$110 \mathrm{~B} . \mathrm{C}$.

$2570 \pm 80$

620 в.C.

$3350 \pm 80$

1400 B.C.

$2920 \pm 70$

970 B.C.

$2690 \pm 80$

740 B.C.

$8500 \pm 120$

6550 B.C.

$10,390 \pm 190$ 8440 B.C.

$9810 \pm 180$ 7860 B.C.

$11,470 \pm 160$ 9520 B.C.

$12,330 \pm 220$ 10,980 B.C.

$17,390 \pm 460$ 15,440 B.с.

$1750 \pm 50$ A.D. 200

$$
\begin{gathered}
2460 \pm 60 \\
510 \text { B.C. } \\
2210 \pm 70 \\
260 \text { B.C. } \\
2580 \pm 70 \\
630 \text { B.C. }
\end{gathered}
$$


BONN-1131. $35.6 \% \mathrm{C}, \mathrm{T} 580$ to $100 \mathrm{~cm}$

\begin{tabular}{|c|c|c|c|}
\hline & & Carbonate $\mathrm{C}$ & Organic $\mathrm{C}$ \\
\hline BONN-967. & $\begin{array}{l}\text { Selent lake, Profile } V \text {, in } \\
\text { lake center ahead of } \\
\text { narrowing NE branch } \\
\text { towards Giekau, taken } \\
\text { by Livingstone borer, } \\
0.7 \% \mathrm{C}, 0 \text { to } 20 \mathrm{~cm} \text {. }\end{array}$ & $\begin{array}{l}24,590 \pm 690 \\
22,640 \text { в.с. }\end{array}$ & $\begin{array}{l}106.3 \pm 0.2 \\
\text { Modern }\end{array}$ \\
\hline BONN-968. & $0.4 \%, \mathrm{C}, 20$ to $40 \mathrm{~cm}$ & $\begin{array}{l}28,500 \pm 1100 \\
26,550 \text { B.C. }\end{array}$ & $\begin{array}{l}470 \pm 110 \\
\text { A.D. } 1480\end{array}$ \\
\hline BONN-969. & $0.7 \% \mathrm{C}, 40$ to $60 \mathrm{~cm}$ & $\begin{array}{l}27,810 \pm 820 \\
25,860 \text { в.C. }\end{array}$ & $\begin{array}{l}3160 \pm 330 \\
1210 \text { B.C. }\end{array}$ \\
\hline BONN-970. & $0.5 \% \quad \mathrm{C}, 60$ to $80 \mathrm{~cm}$ & $\begin{array}{l}30,280 \pm 1200 \\
28,330 \text { в.с. }\end{array}$ & $\begin{array}{l}6660 \pm 510 \\
4710 \text { в.с. }\end{array}$ \\
\hline BONN-971. & $0.4 \% \quad \mathrm{C}, 80$ to $100 \mathrm{~cm}$ & $\begin{array}{l}29,170 \pm 1190 \\
27,220 \text { B.C. }\end{array}$ & $\begin{array}{l}9070 \pm 420 \\
7120 \text { в.с. }\end{array}$ \\
\hline BONN-972. & $0.6 \% \mathrm{G}, 100$ to $120 \mathrm{~cm}$ & $\begin{array}{l}37,810 \pm 3190 \\
35,860 \text { в.C. }\end{array}$ & $\begin{array}{l}8640 \pm 420 \\
6690 \text { в.c. }\end{array}$ \\
\hline BONN-973. & $0.3 \% \mathrm{C}, 120$ to $140 \mathrm{~cm}$ & $\begin{array}{l}32,940 \pm 1870 \\
30,990 \text { в.C. }\end{array}$ & $\begin{array}{l}11,650 \pm 590 \\
9700 \text { в.C. }\end{array}$ \\
\hline BONN-974. & $0.4 \% \mathrm{C}, 140$ to $160 \mathrm{~cm}$ & $\begin{array}{l}37,600 \pm 3310 \\
35,650 \text { B.C. }\end{array}$ & $\begin{array}{c}10,620 \pm 390 \\
8670 \text { в.C. }\end{array}$ \\
\hline BONN-975. & $0.5 \% \mathrm{C}, 160$ to $180 \mathrm{~cm}$ & $\begin{array}{l}37,890 \pm 2980 \\
35,940 \text { в.С. }\end{array}$ & $\begin{array}{c}10,930 \pm 460 \\
8980 \text { в.с. }\end{array}$ \\
\hline BONN-976. & $0.4 \% \mathrm{C}, 180$ to $200 \mathrm{~cm}$ & $\begin{array}{l}36,250 \pm 2660 \\
34,300 \text { в.С. }\end{array}$ & $\begin{array}{l}14,180 \pm 670 \\
12,230 \text { в.с. }\end{array}$ \\
\hline BONN-977. & $\begin{array}{l}\text { Selent lake, Profile VI, bay } \\
\text { taken by Livingstone borer } \\
0 \text { to } 20 \mathrm{~cm} \text {. Samples from san }\end{array}$ & $\begin{array}{l}\text { near Seckrug, } \\
\text { r, } 11.7 \% \mathrm{C} \\
\text { me location. }\end{array}$ & $\begin{aligned} 780 \pm 70 \\
\text { A.1. } 1170\end{aligned}$ \\
\hline BONN-978. & $10.1 \% \mathrm{C}, 20$ to $40 \mathrm{~cm}$ & & $\begin{array}{r}980 \pm 90 \\
\text { A.D. } 970\end{array}$ \\
\hline BONN-979. & $7.1 \% \mathrm{C}, 40$ to $60 \mathrm{~cm}$ & & $\begin{array}{r}1580 \pm 80 \\
\text { A.D. } 370\end{array}$ \\
\hline BONN-980. & $5.1 \% \mathrm{C}, 60$ to $80 \mathrm{~cm}$ & & $\begin{array}{c}2290 \pm 80 \\
340 \text { B.C. } \\
2970 \pm 110\end{array}$ \\
\hline BONN-981. & $6.6 \%$ C, 80 to $96 \mathrm{~cm}$ & & 1020 B.C. \\
\hline
\end{tabular}


BONN-982. $9.5 \% \mathrm{C}, 100$ to $120 \mathrm{~cm}$

BONN-983. $9.8 \%$ C, 120 to $140 \mathrm{~cm}$

BONN-984. $10.2 \% \mathrm{C}, 140$ to $160 \mathrm{~cm}$

BONN-985. $6.3 \%$ C, 160 to $180 \mathrm{~cm}$

BONN-986. $9.2 \% \mathrm{C}, 180$ to $200 \mathrm{~cm}$

BONN-987. $12.6 \%$ C, 200 to $220 \mathrm{~cm}$

BONN-988. $7.6 \%$ C, 220 to $240 \mathrm{~cm}$

BONN-989. $5.7 \%$ C, 240 to $260 \mathrm{~cm}$

BONN $-990 . \quad 1.0 \% \mathrm{C}, 260$ to $280 \mathrm{~cm}$

BONN-991. $1.5 \%$ C, 280 to $300 \mathrm{~cm}$

BONN-992. $\quad 0.6 \% \mathrm{C}, 300$ to $320 \mathrm{~cm}$

BONN-993. $0.2 \% \mathrm{C}, 320$ to $340 \mathrm{~cm}$
$3120 \pm 80$

1170 B.C.

$2350 \pm 90$

400 в.C.

$3430 \pm 80$

1480 B.c.

$4260 \pm 110$

2310 в.С.

$4850 \pm 90$

2900 в.C.

$4670 \pm 120$

2720 B.C.

$4850 \pm 100$

2900 в.c.

$5870 \pm 230$

3920 B.c.

$5940 \pm 180$

3390 в.C.

$5590 \pm 360$

3640 B.c.

$10,080 \pm 520$

8130 B.c.

$30,930 \pm 1150$

28,980 B.c.

Samples coll. and subm. 1969 by H. W. Scharpenseel, W. Kerpen, and H. Gewehr. Comment: as in Schalkenmehren series, the extent of anthropogenic influence, exerted on sampling sites, correlates with age vs. depth pattern of profiles. Selent I and II sites are close to present day village Giekau and a presumed submerged prehistoric settlement. Profile I is young, it has maximum dates of $7000 \mathrm{yr}$. Selent III to VI date to $25,000 \mathrm{yr}, 17,000 \mathrm{yr}, 14,200 \mathrm{yr}$, and $10,000 \mathrm{yr}$ (with a doubtful jump to 31,000 yr in deepest sample, which should be verified). The lake sediment was possibly influenced by partly available free carbonates (Münnich, 1957; Münnich and Vogel, 1959). Selent $V$ was tested on the basis of carbonate $\mathrm{C}$ as well as on remaining organic $\mathrm{C}$. Results show no strict relationship, except for general trend of age vs. depth increase. Results suggest, that formation of Selent lake sediment began at least since Boelling, or even Paudorf interval. Measurement of apparent mean residence time in 2 soil profiles on shore, opposite Profile I and IV, reveals young lake alluvium, just as in Profile 1, or at Selent lake beach 
(opposite Profile IV) peat layers up to $2700 \mathrm{yr}$, indicating filling of certain parts of lake fringes by low moor formation since Sub-Boreal.

\section{Iran series}

V. ARCHAEOLOGIC SAMPLES

Age of old mine, S fringe of Great Kavir, Central Iran, Chah Nukluk or Nakhlak, dated through work on 3 buildings from Sasanitic origin (4 to 7 th century), ( $33^{\circ} 12^{\prime} \mathrm{N}$ Lat, $53^{\circ} 46^{\prime} \mathrm{E}$ Long).

\section{BONN-1666.}

$$
1790 \pm 100
$$

Relic of decaying supporting pole, assoc. archeol. materials, mining tools, wedges, earthen ware.

\section{BONN-1667.}

$$
1190 \pm 80
$$

Parts of 2 wooden containers, assoc. archcol. materials, mining tools, wedges, earthen ware.

\section{BONN-1668.}

$$
1820 \pm 80
$$

Truncated wooden pole, in gate of antique fort, beside 2 Sasaniclic fire temples. Samples coll. and subm. 1971 by U. W. Hallier, Inst. Bot., Düsseldorf Univ. Comment: dates agree with expectations.

\section{Netherrhine series}

Dates different buildings or parts of buildings of Burg Meer, Meerbusch-Büderich, Kreis Grevenbroich as part of regional study by Dr. Janssen, Rheinisches Landesmus. Bonn, (51 $11^{\circ} \mathrm{N}$ Lat, $6^{\circ} 41^{\prime}$ E Long).

\section{BONN-1673.}

$1130 \pm 70$

Burning relics of wooden Building VI, $120 \mathrm{~cm}$ below surface.

\section{BONN-1674.}

Roof cover, oak wood, Building III.

\section{BONN-1675.}

Palisade pole, layer younger Period B.

\section{BONN-1676.}

Slice of oak tree, layer younger Period B.

\section{BONN-1677.}

Roof cover, oak wood, Building III.

\section{BONN-1678.}

Burning relics, wooden Building V.
A.D. 820

$1130 \pm 70$ A.D. 820

A.D. 1040

$$
910 \pm 70
$$

$$
1100 \pm 70
$$

A.D. 850

$$
1090 \pm 70
$$

A.D. 860

$$
1140 \pm 80
$$

A.D. 180 
BONN-1679.

Wooden swimmer from fishing net.

BONN-1680.

Parts of oak wooden Boat III. Samples coll. and subm. 1971 by Dr. Janssen. Comment: cstimated age of samples, 11 to 12 th century, exceeded by measured dates, except for BONN-1675 and BONN-1679.

\section{REFFRENCFS}

Blackburn, (i. and Coppi, J. A., 1970, Gilgai soils, details of samples, Kaniva District, Victoria: CSIRO, Div. Soils, I cech. Memo, 50, 1970.

Dietz, Th., I971, Landschaften und Böden in der Bundestepublik Deutschland: Deutsch. Bodenkundl. Gesell. Mitt., v. 13, p. 479-519.

Erlenkäuscr, H., Straka, H., and Willkomm, H., 1970, Neue C14-1)atierungen zum Nlter der EifeImaare: Eiszeitalter u. Gegenwart, v. "21, p. 177-181.

Frechen, J., 1971, Siebengebirge am Rhein, Iaacher Vulkangebiet, Maargebiet der Westeifel: Sammlung ficol, liuhrer, Berlin, Bornträger,

Mückenhausen, E., Schapensed, II. W., and Pietig, F., 1968, Zum Alter des Plaggeneschs: Eiszeitalter u. Gegenwart, v. 19, p. I90-196.

Mümuich, K. O., 1957, Messungen des $C^{11}$-Gehaltes von hartem Grundwasser; Naturwissenschaften, v. 44, p. $32-33$.

Mümmich, K. O. and Vogel, J. C., 1959, C ${ }^{14}$-Altersbestimmungen von SüsswasserKalkablagerungen: Naturwissenschaften, v. 46, p. 168-169.

Scharpenseel, H. W., I970, Radiocarbon dating of soils-problems, troubles, hopes, m: D. H. Yaalon (ed.), Palcopedology-origin, nature and dating of Paleosols: Internatl. Soil Sci. Soc, p. 77-88.

- 1972, Natural radiocarbon measurements on soil organic matter fractions and on soil profiles of diflerent pedogenesis: Lnternatl. radiocarbon dating Conf., Lower Hutt, New Zealand (in press)

Scharpensecl, 11. W. and Pietig, F., 1969, Einfache Boden-und Wasserdatierung durch Messung der C ${ }^{14}$ oder Tritiumkonzentration: Geoderma, v. 2, p. 273-289. 1970, University of Bonn natural radiocarbon measurements III: Radiocarbon, v. 12 , p. $19-39$.

1971, University of Bonn natural radiocarbon measurements IV: Radiocarbon, v. 13, p, 189-212.

1973, University of Bonn natural radiocarbon measurements $V$ : Radiocarbon, v. 15, p. $13-41$

Tamers, M. A. and Scharpenseel, H. W., 1970, Sequential sampling of radiocarbon in groundwater: IAEA Isotope Hydrology Conf., Vienna, p. 241-257. 